\title{
POWDER FORMULATION OF ANTAGONISTIC YEASTS, CRYPTOCOCCUS ALBIDUS AND CRYPTOCOCCUS TERREUS AS BIOFUNGICIDES
}

\author{
SURYO WIYONO* and WIDODO \\ ${ }^{1}$ Department of Plant Protection, Faculty of Agriculture, Bogor Agricultural University \\ Darmaga, Bogor-Indonesia
}

Recipient of BIOTROP Research Grant 2009/Accepted 14 May 2012

\begin{abstract}
This study aimed 1) to investigate the compatibility of yeast antagonists i.e. C. albidus and $C$. terreus, 2) to obtain suitable carrier in powder formulation for those two yeasts, 3) to get appropriate formulation additives for those yeasts, and 4) to obtain optimum powder formulation consisting of yeasts, carrier materials and additives. Compatibility of C. albidus and C. terreus were tested through bio-assay against Lasiodiplodia theobromae on detached banana fruit and Alternaria solani on detached tomato leaves. Compatibility was indicated by no reduction of antagonistic activity. Benomyl-resistant mutant of C. albidus and cycloheximide-resistant mutant of $C$. terreus were mixed with sterilized tapioca, talc and kaolin to get initial yeasts density of 8.5 $\log \mathrm{cfu} / \mathrm{g}$ and water content of $15 \%$, then packed in plastic bag and stored under room temperature. Survival of formulated yeasts was assessed monthly by planting on PDA medium containing $150 \mathrm{ppm}$ cycloheximide for C. terreus, and $150 \mathrm{ppm}$ benomyl for C. albidus. Yeasts population was expressed in $\log \mathrm{cfu} / \mathrm{g}$ materials. To determine the effect of carrier materials on antagonistic activity, bio-assay of formulated yeasts against pathogens was conducted after 3 months of storage. Tested additives i.e. $\mathrm{CaCl}_{2}$, pure chitin and crab shell powder were added into suspension of C. albidus and C. terreus to get concentration of $1.25 \%, 0.5 \%$ and $0.1 \%(\mathrm{w} / \mathrm{v})$. Sterilized distilled water and yeasts without additives was used as control. Then, the treatments were examined for the antagonistic activity through bio-asaay on detached banana fruits and tomato leaves. Appropriate additive(s) was determined by its ability to increase antagonistic activity of yeasts. Storability and antagonistic activity of $C$. albidus and $C$. terreus in the mixture of best carrier and additive were examined. Cryptococcus terreus was compatible to C. albidus. Talc was the best carrier material supporting highest survival of $C$. terreus, without contamination of other microorganisms. Talc was the best carrier material for C. albidus formulation by maintaining its survival for six months of storage. Additives able to increase antagonistic activity of $C$. terreus were $\mathrm{CaCl}_{2} 0.1 \%$, pure chitin $0.1 \%$ and crab shell powder $0.5 \%$. All of tested additives materials did not affect antagonistic activity of C. albidus. Supplementation of chitin and crab shell, both at the rate of $1.25 \%$ into talc-base powder formulation increased survival of C. terreus and C. albidus.
\end{abstract}

Key words: formulation, yeast antagonists, Cryptococcus terreus, Cryptococcus albidus, carrier agent, talc, tapioca, kaolin, $\mathrm{CaCl}_{2}$, chitin, crab shell powder

\footnotetext{
*Corresponding author : suryow@hotmail.com
} 


\section{INTRODUCTION}

A group of novel promising biocontrol agents of plant disease are antagonistic yeasts. The advantage of yeast as biocontrol agent is dry and heat tolerance, therefore, adaptable on leaves and other aerial plant parts. It is fast growing, easy to be mass cultured and socially more acceptable (Spadaro 2003).

Research in foreign countries showed the effectiveness of yeast in controlling plant disease. A yeast antagonist Metschnikowia pulcherrima was reported effective to control apple rot disease caused by Penicillium (Spadaro 2003). Moreover, near harvest application of Metschnikowia fructicola effectively control post harvest disease of grapefruit (Karabulut et al. 2003). Botrytis cinerea on tomato plants was reported to be effectively controlled by the use of epiphytic yeasts Candida guilliermondii strains 101 and US 7 and Candida oleophila (Saligkarias et al.2002).

Cryptococcus albidus and Cryptococcus terreus collected by the authors have been screened for their antagonistic activity in vitro, bio-assay in vivo, field test and partially characterized. Cryptococcus albidus and Cryptococcus terreus were effective yeast antagonists against stem end rot of mango caused by Lasiodiplodia theobromae and petal blight of orchid caused by Curvularia pallescens, respectively (Wiyono 2008; Sugiprihatini 2009). Recently, the second yeast is also effective tested against leaf blight of tomato caused by Alternaria solani and chrysanthemum white rust caused by Puccinia horiana. In addition, Fan and Tian (2001) reported that Crypococcus albidus is also effective in controlling apple post harvest diseases i.e. grey mold and blue mold.

After obtaining superior isolates of antagonists, technology for mass production and formulation is required to develop an antagonist as biocontrol agent on commercial scale. Since those two yeasts are relatively easy to be mass cultured in a cheap medium (potato dextrose broth PDB), formulation technology is a critical step. Suitable formulation technology is the main limiting factors in developing microbial pesticides in Indonesia, even high numbers of effective antagonists had been isolated (Santoso et al. 2005). Appropriate formulation technology will facilitate storage, transportation, application technique and also bio-performance of antagonists. Solid formulation is chosen to be developed for easier transportation and handling.

Formulation of beneficial microbes contains microbes, carrier and additives. Combination of microbes will broaden the target of bio-fungicide. Optimization of whole components ensures the quality of formulation and further commercial application. Some minerals such as kaolin and talc can be used as carrier in formulation of Metschnikowia pulcherrima and Pichia guilliermondii (Kinay \& Yildiz 2008). Additives play also an important role in biocontrol performance. Calcium chloride and chitin were used as additive enhancing antagonistic activity of yeasts antagonists Candida guilliermondii, Pichia membranefaciens, and Cyptococcus laurentii. Compatibility of the two yeast antagonists, appropriate as carrier materials and additives for C.albidus and $C$. terreus has not been investigated yet.

The objectives of the research were: 1) to assess the compatibility of two yeast antagonists $C$. albidus and $C$. terreus, 2)to obtain cheap material as carrier agent which ensure long time survival and bio-performance of $C$. albidus and $C$. terreus, 3 ) to get formulation additives supporting storability and bioperformance of yeast antagonist 
C. albidus and C. terreus., and 4) to obtain optimum solid formulation in combination with yeasts, carrier material and additives.

\section{MATERIALS AND METHODS}

\section{Yeast and pathogen preparation}

Antagonistic yeasts used were Cryptococcus albidus and C. terreus obtained from the author's collection. For formulation purpose, benomyl-resistant mutant of $C$. albidus which is similar to antagonistic activity was generated. In addition, $C$. terreus resistant to cycloheximide was used in formulation experiment. Lasiodiplodia theobromae and Alternaria solani collections of the author were used for bio assay of yeasts. Both of the two yeast antagonists were cultured in potato dextrose broth (PDB Difco) and harvested at early stationary phase of growth, centrifuged at $5000 \mathrm{~g}$ (Jouan Centrifuge BR4i), washed with sterilized distilled water, mixed with saline solution adjusted to appropriate density. Lasiodiplodia theobromae was cultured on PDA (Difco) pH 5.5 for seven days and the conidia harvested by soaking water on the surface and filtered with cheese cloth. Alternaria. solani was cultured on S-medium and incubated for seven days under NUV exposure to induce sporulation (Abadi 1987), prior to harvesting of conidia.

\section{Bio-assay of antagonistic activity of yeasts}

Bio-assay of yeast antagonists was conducted based on previous technique developed by the authors using detached banana fruits and detached leaves of tomato. The detached organs were placed on moistened plastic pans $(30 \mathrm{~cm} \times 25 \mathrm{~cm} \times 5 \mathrm{~cm}$ ), one plastic pan contained five banana fruits or tomato leaves. Detached banana fruits were dipped in cell suspension of C. albidus at $7 \log \mathrm{cfu} / \mathrm{mL}$, while the detached leaves were dipped in cell suspension of C. terreus $7 \log \mathrm{cfu} / \mathrm{mL}$, both added with wetting agent Tween $20,0.005 \%$. Then the treated banana fruits and tomato leaves were air dried. Sterilized distilled water was used as control. Conidia suspension at $50 \mu \mathrm{l}$ of $L$. theobromae and A. solani, both at the density of $10^{4}$ conidia $/ \mathrm{mL}$ was placed on the surface of fruit and leaves, respectively. Inoculated fruits and leaves were stored under dark condition for 24 hours and then incubated under room temperature $\left(27^{\circ} \mathrm{C}\right)$ and photoperiods of 12: 12 (D:L). Disease severity was assessed by estimating of necrosis part at five days after inoculation and expressed in percent. Effective treatment was indicated by low disease severity.

\section{Compatibility of C. albidus and C. terreus}

The treatment consists of $C$ albidus, $C$. terreus, a mixture of $C$ albidus and $C$. terreus, and untreated (water). Each treatment was replicated five times. Yeast concentration used for compatibility test was $5 \times 10^{6} \mathrm{cfu} / \mathrm{mL}$ for $C$. albidus and $5 \times 10^{6} \mathrm{cfu} / \mathrm{mL} C$. terreus, therefore obtaining final concentration of $7 \log \mathrm{cfu} / \mathrm{mL}$, with ratio of $1: 1$, and added with wetting agent Tween 20, $0.005 \%$. Bio-assay was conducted on detached fruit of banana and detached leaves of tomato (see bio-assay of antagonistic activity). 
If the two yeasts are compatible, it will be further tested in a formulation experiment.

\section{Screening for carrier materials}

Materials tested for carrier were kaolin powder, talc powder and tapioca. Each material was regarded as treatment and replicated five times. The materials were sterilized by standard autoclaving. Suspension of two yeast antagonists and its mixture (preparation mentioned above) was mixed by spraying (hand sprayer Yoto 1-L, made in Indonesia) yeast suspension on the tested materials in running blender, then air dried to get final yeast density of $8.5 \mathrm{log} \mathrm{cfu} / \mathrm{g}$ with $15 \%$ of water content of formulation. Materials containing yeast were then packed in plastic bags and stored under room temperature for 6 months. Each material containing yeast was assessed for yeast survival and antagonistic activity every 30 days for six months. Survival of yeast in each carrier materials was determined by plating on PDA (Difco) $\mathrm{pH} 5.5$ containing $150 \mathrm{ppm}$ benomyl for C. albidus, and $150 \mathrm{ppm}$ cycloheximide for C. terreus. Colony isolated from each carrier material of three month storage was then tested for its antagonistic activity using the technique as described in bioassay of antagonistic activity.

\section{Screening for additives}

Materials screened for additives are pure chitin (Sigma), natural material containing chitin i.e. crab shell powder, and calcium chloride. Methods for testing the formulation additives are based on previously developed technique (Wiyono et al. 2008). Each material was tested with water-based suspension/solution at the rate of $1.25 \% ; 0.5 \%$; $0.1 \%$ (w/v). Suspension of C. albidus and C. terreus at density of $7 \mathrm{log} \mathrm{cfu} / \mathrm{mL}$ mixed with the tested additives and final concentration of additives was adjusted to the tested

concentration. Yeast suspension without addition of tested materials was used as control. Yeasts with various additives treatment was furthermore tested for their antagonistic activity using the technique as described in bioassay of antagonistic activity.

\section{Combination of suitable yeast composition, carrier materials and additives}

Best results obtained from previous experiment with yeasts compatibility, carrier materials and additives were then continued to test for suitable powder formulation . Combination of yeasts, selected carrier materials, selected additives in powder

formulation was conducted. The survival and antagonistic activity were also assessed every 30 days for four months.

\section{RESULTS AND DISCUSSION}

\section{Compatibility of C.terreus dan C.albidus}

The research showed that $C$. terrreus was compatible to C. albidus. Effectiveness 
of the two yeast antagonists did not decrease in mixed application (Tables 1 and 2). The compatibility of the two yeasts make broader spectrum of the mixture. One important advantage of antagonists combination is the possibility to obtain a broader spectrum (Burges \& Jones 1998).

Table 1. Compatibility of Cryptococcus albidus and C. terreus in controlling fruit rot of banana caused by $L$. theobromae

\begin{tabular}{lc}
\hline Treatment & Disease severity (\%) \\
\hline Untreated & $34.53 \mathrm{~b}$ \\
Cryptococcus albidus & $26.00 \mathrm{ab}$ \\
Cryptococcus terreus & \\
C. terreus + C. albidus & $7.53 \mathrm{a}$ \\
\hline
\end{tabular}

Note:

Numbers followed by same symbol are not significantly different at $\mathrm{p}<0.05$ with DRMT test

Table 2. Compatibility of Cryptococcus albidus and C. terreus in controlling alternaria leaf blight of tomato caused by Alternaria solani

\begin{tabular}{lc}
\hline Treatment & Disease severity (\%) \\
\hline Untreated & $10.58 \mathrm{~b}$ \\
Cryptococcus terreus & $5.55 \mathrm{a}$ \\
C. terreus + C. albidus & $5.48 \mathrm{a}$ \\
\hline
\end{tabular}

Note:

Numbers followed by same symbol are not significantly different at $\mathrm{p}<0.05$ with DRMT test

\section{Survival of C. terreus dan C. albidus in various carrier materials}

Carrier materials are important component of formulation for maintaining microbes survival and antagonistic activity. Among materials tested for $C$. terreus, tapioca provided the highest survival. Overall, $C$. terreus could survive in all tested carriers for four months. During five months of storage $C$. terreus could not be detected anymore in all of the tested materials (Table3). Talc powder provided highest survival for C. albidus (Table 4). Up to six months of storage, talc powder still resulted in relatively high C. albidus survival ( $4.60 \log \mathrm{cfu} / \mathrm{g}$ ).

Even though tapioca is the best material for $C$. terreus storage, it has high contamination level of other fungi. Tapioca is an organic flour, hence it can act as nutrition for some other fungi and bacteria. This was not the case with mineral powder such as kaolin and talc. Kinay and Yildiz (2007) stated that talc in granular formulation is able to provide storability of antagonistic yeasts Metschnikowia pulcherrima and Pichia guilliermondii for more than 6 months. Storability of talc was better than kaolin. Storability of talc in this experiment was lower than that reported by Kinay and Yildiz (2007), because this experiment used powder formulation instead of granular form.

The use of talc as carrier material in powder formulation is also able to maintain bio-performance of the two yeasts in storage (Tables 5 and 6 ). Antagonistic activity of 
BIOTROPIA Vol. 20 No. 1, 2013

Table 3. Survival of C. terreus on various carrier materials in powder formulation

\begin{tabular}{lcrrrrr}
\hline \multirow{2}{*}{$\begin{array}{c}\text { Carrier } \\
\text { Materials }\end{array}$} & \multicolumn{6}{c}{ Yeast density $(\log \mathrm{cfu} / \mathrm{g})$ in i-th month } \\
\cline { 2 - 7 } & 0 & 1 & 2 & 3 & 4 & 5 \\
\hline Tapioca & $8.70 \mathrm{a}$ & $7.06 \mathrm{~b}$ & $7.23 \mathrm{~b}$ & $7.36 \mathrm{~b}$ & $4.18 \mathrm{~b}$ & - \\
Talc & $8.65 \mathrm{a}$ & $6.00 \mathrm{a}$ & $6.54 \mathrm{a}$ & $5.69 \mathrm{a}$ & $4.50 \mathrm{~b}$ & - \\
Kaolin & $8.65 \mathrm{a}$ & $6.67 \mathrm{a}$ & $6.24 \mathrm{a}$ & $6.26 \mathrm{a}$ & $3.82 \mathrm{a}$ & - \\
\hline
\end{tabular}

Note:

- = undetected

Numbers followed by same symbol are not significantly different at $\mathrm{p}<0.05$ with DRMT test

Table 4. Survival of C. albidus on various materials in powder formulation

\begin{tabular}{|c|c|c|c|c|c|c|c|}
\hline \multirow{2}{*}{$\begin{array}{l}\text { Carrier } \\
\text { Materials }\end{array}$} & \multicolumn{7}{|c|}{ Yeast density $(\log \mathrm{cfu} / \mathrm{g})$ in i-th month } \\
\hline & 0 & 1 & 2 & 3 & 4 & 5 & 6 \\
\hline Tapioca & $8.24 \mathrm{a}$ & $5.95 \mathrm{a}$ & $6.98 \mathrm{a}$ & $4.21 \mathrm{a}$ & - & - & - \\
\hline Talc & $8.72 \mathrm{a}$ & $5.70 \mathrm{a}$ & $6.65 \mathrm{a}$ & $5.98 \mathrm{~b}$ & 6.17 & 4.20 & 4.65 \\
\hline Kaolin & $8.60 \mathrm{a}$ & $5.25 \mathrm{a}$ & - & - & - & - & - \\
\hline
\end{tabular}

Note:

$-=$ Undetected

Numbers followed by same symbol are not significantly different at $\mathrm{p}<0.05$ with DRMT test

Table 5. Antagonistic activity of C. terreus formulated with different carrier materials against alternaria leaf blight of tomato (after 3 months storage)

\begin{tabular}{lc}
\hline Carrier Materials & Alternaria leaf blightseverity $(\%)$ \\
\hline Control (water) & $7.64 \mathrm{~b}$ \\
Unformulated fresh yeast & $2.13 \mathrm{a}$ \\
Tapioca & $0 \mathrm{a}$ \\
Talc & $2.12 \mathrm{a}$ \\
Kaolin & $1.13 \mathrm{a}$ \\
\hline
\end{tabular}

Note:

Numbers followed by same symbol are not significantly different at $\mathrm{p}<0.05$ with DRMT test

Table 6. Antagonistic activity of C. albidus formulated with different carrier materials against fruit rot of banana (after 3 month storage)

\begin{tabular}{lc}
\hline Carrier Materials & $\begin{array}{c}\text { Fruit rot severity } \\
(\%)\end{array}$ \\
\hline Control (water) & $16.23 \mathrm{~b}$ \\
Unformulated fresh yeast & $5.24 \mathrm{a}$ \\
Tapioca & $9.14 \mathrm{a}$ \\
Talc & $5.22 \mathrm{a}$ \\
Kaolin & - \\
\hline Note: & \\
Numbers followed by same symbol are not significantly different at $\mathrm{p}<0.05$ with DRMT test
\end{tabular}


C. albidus and C. terreus in all tested materials (except kaolin) did not decrease after 3 months of storage indicated by no significant difference to unformulated fresh yeast.

Additives-mediated enhancement of antagonistic activity of C. terreus and $C$. albidus.

Formulation additives such as additional nutrients are often important in formulation of beneficial microbes. Some formulation additives are able to increase antagonistic activity of antagonistic microbes, for example zinc and manganese can improve antagonistic activity of Pseudomonas fluorescens B5 (Wiyono et al. 2008). Among tested additives, $\mathrm{Ca} \mathrm{Cl}_{2} 0.1 \%$, pure chitin $0.1 \%$ and crab shell powder $0.5 \%$ significantly increase antagonistic activity of C. terreus (Table 7). Even though there was no significant difference among the three treatments, crab shell powder provided highest increase of antagonistic activity.

Additives treatment did not increase significantly antagonistic activity of C. albidus, however $\mathrm{CaCl}_{2} 0.5 \%$, crab shell powder $1.25 \%$ and pure chitin $1.25 \%$ tend to increase

Table 7. Effect of additives on the antagonistic activity of $C$. terreus

\begin{tabular}{llc}
\hline Treatment & Conc. $(\% \mathrm{w} / \mathrm{v})$ & Alternaria leaf blight severity $(\%)$ \\
\hline Water & & $25.45 \mathrm{e}$ \\
Yeast without additives & $9.52 \mathrm{~cd}$ \\
$\mathrm{Ca} \mathrm{Cl}$ & 1.25 & $7.12 \mathrm{abcd}$ \\
$\mathrm{Ca} \mathrm{Cl}$ & 0.5 & $5.35 \mathrm{abc}$ \\
$\mathrm{Ca} \mathrm{Cl}$ & 0.1 & $4.52 \mathrm{ab}$ \\
$\mathrm{Chitin}$ & 1.25 & $10.00 \mathrm{~d}$ \\
$\mathrm{Chitin}$ & 0.5 & $8.35 \mathrm{bcd}$ \\
$\mathrm{Chitin}$ & 0.1 & $4.25 \mathrm{ab}$ \\
Crab shell powder & 1.25 & $4.80 \mathrm{ab}$ \\
Crab shell powder & 0.5 & $3.14 \mathrm{a}$ \\
Crab shell powder & 0.1 & $3.94 \mathrm{ab}$ \\
\hline
\end{tabular}

Note:

Numbers followed by same symbol are not significantly different at $\mathrm{p}<0.05$ with DRMT test

Table 8. Effect of additives on the antagonistic activity of C. albidus

\begin{tabular}{lll}
\hline Treatment & Conc. $(\% \mathrm{w} / \mathrm{v})$ & Fruit rot severity $(\%)$ \\
\hline Water & & $55.00 \mathrm{c}$ \\
Yeast without additives & & $35.00 \mathrm{ab}$ \\
$\mathrm{Ca} \mathrm{Cl}_{2}$ & 1.25 & $41.25 \mathrm{ab}$ \\
$\mathrm{Ca} \mathrm{Cl}_{2}$ & 0.5 & $21.25 \mathrm{a}$ \\
$\mathrm{Ca} \mathrm{Cl}_{2}$ & 0.1 & $43.75 \mathrm{ab}$ \\
$\mathrm{Chitin}$ & 1.25 & $15.75 \mathrm{a}$ \\
Chitin & 0.5 & $53.75 \mathrm{~b}$ \\
Chitin & 0.1 & $43.75 \mathrm{ab}$ \\
Crab shell powder & 1.25 & $21.25 \mathrm{a}$ \\
Crab shell powder & 0.5 & $41.25 \mathrm{ab}$ \\
Crab shell powder & 0.1 & $43.75 \mathrm{ab}$ \\
\hline Not
\end{tabular}

Note:

Numbers followed by same symbol are not significantly different at $\mathrm{p}<0.05$ with DRMT test 
antagonistic activity (Table 8). Furthermore, crab shell powder 1.25\% was used in powder formulation containing mixture of $C$. terreus and C. albidus, because its effect is not significant to chitin and its price is far cheaper than pure chitin.

The research result was in line with previous researches in other yeasts. Antagonistic activity of yeast (various species or isolates) can be enhanced by addition of calcium chloride (Tian et al. 2002; Abadias et al. 2003), pure chitin (Vivekananthan et al. 2004; Yu et al. 2007). Calcium chloride could increase the biocontrol efficacy of tested yeast due to its ability to enhance plant resistance against plant diseases (Biggs $e t$ al. 1997; Droby et al. 2003). The same mechanism is similar for chitin (Yu et al. 2007). This research resulted in a new finding that crab shell powder, a chitin-containing material, provides the same level of enhancement compared to pure chitin. The mechanism how crabshell increase antagonistic activity of $C$. terreus is not exactly known, probably it involves induction of plant resistance. Harti (2010) reported induced resistance of banana against fusarial wilt diseases after treated with crab shell powder. Aside from chitin, crab shell contains protein, calcium, phosphate, and other elements such as iron, manganese and zinc (Multazam 2002), therefore effect of composing elements of crab shell powder on antagonistic activity could not be ignored. This is an advantage since using crab shell powder is cheaper than pure chitin. The use of crab shell powder does not need chemicals for processing, so it is costeffeective.

\section{Effect of crab shell powder as additives in talc-based powder formulation of $C$. terreus and C. albidus}

One strategy to improve storability and bio-performance of formulated microbes is by providing additives (Burges \& Jones 1998; Fravel 2005; Wiyono et al. 2008). Some additives of antagonistic yeasts are metal ion (calcium), sugar (trehalose), biopolymer (chitin) and calcium (Abadias et al. 2003). Addition of crab shell 1.25\% into talc-based

Table 9. Survival of C. terreus in talc formulation and supplemented with additives

\begin{tabular}{|c|c|c|c|c|}
\hline \multirow{2}{*}{ Treatment } & \multicolumn{4}{|c|}{ Yeast density $(\log \mathrm{cfu} / \mathrm{g})$ in i-th month } \\
\hline & 0 & 1 & 2 & 3 \\
\hline Talc & $8.7 \mathrm{a}$ & $6.15 \mathrm{a}$ & $6.54 \mathrm{a}$ & $5.02 \mathrm{a}$ \\
\hline Talc + Chitin & $8.19 \mathrm{a}$ & $7.89 \mathrm{~b}$ & $6.75 \mathrm{a}$ & $5.02 \mathrm{a}$ \\
\hline Talc + crab shell powder & $8.73 \mathrm{a}$ & $7.00 \mathrm{ab}$ & $6.07 \mathrm{a}$ & $6.07 \mathrm{~b}$ \\
\hline
\end{tabular}

Numbers followed by same symbol are not significantly different at significant level of 0.05 with DMRT test

Table 10. Survival of C. albidus in talc formulation and supplemented with additives

\begin{tabular}{lcccc}
\hline \multirow{2}{*}{ Treatment } & \multicolumn{5}{c}{ Yeast density } & \multicolumn{1}{c}{$(\log \mathrm{cfu} / \mathrm{g})$} & in i-th month \\
\cline { 2 - 5 } & 0 & 1 & 2 & 3 \\
\hline Talc & $8.87 \mathrm{a}$ & $6.06 \mathrm{a}$ & $6.50 \mathrm{a}$ & $5.26 \mathrm{a}$ \\
Talc + Chitin & $9.31 \mathrm{a}$ & $7.56 \mathrm{~b}$ & $6.48 \mathrm{a}$ & $5.14 \mathrm{a}$ \\
Talc + Crab shell powder & $9.56 \mathrm{a}$ & $7.30 \mathrm{~b}$ & $6.22 \mathrm{a}$ & $6.06 \mathrm{~b}$ \\
\hline
\end{tabular}

Numbers followed by same symbol are not significantly different at $\mathrm{p}<0.05$ with DRMT test 
formulation increased survival of C. terreus and C. albidus (Tables 9 and 10). Further studies on the exploration and optimization of various additives are needed to prolong survival rate of formulated yeasts.

\section{CONCLUSIONS}

C. terreus is compatible to C. albidus, therefore it can be used in a mixture formulation. Best carrier materials in powder formulation of $C$. terreus was talc, able to maintain yeast survival for four months of storage without contamination of other microorganisms. Talc powder provided best survival of $C$. albidus, with survival more than 5 months of storage. Crab shell at concentration of $1.25 \%$ can be used as additive in powder formulation containing a mixture of $C$. terreus and $C$. albidus, based on its enhancement of antagonistic activity on $C$, terreus and survival of both antagonistic yeasts.

\section{ACKNOWLEDGMENTS}

The authors would like to acknowledge SEAMEO BIOTROP for providing financial support through DIPA 2009. Moreover, the authors express their gratitude to people involved in this research, Ms Ratih Munawaroh and Mr. Dadang Surahman at the Laboratory of Plant Mycology Dept of Plant Protection, Faculty of Agriculture, Bogor Agricultural University.

\section{REFERENCES}

Abadi AL. 1983. Antagonism between leaf surface microorganism and Alternaria solani, causal agent of early blight of tomato (Lycopersicon esculentum). Master Thesis. Graduate School Bogor Agricultural University, Bogor (in Bahasa Indonesia).

Abadias M, Usall J, Teixidó N, Viñas I. 2003. Liquid formulation of the postharvest biocontrol agent Candida sake CPA-1 in isotonic solutions. Phytopathology 93:436-42.

Biggs AR, El-Kholi MM, El-Neshawy S, Nickerson R. 1997. Effects of calcium salts on growth, polygalacturonase activity, and infection of peach fruit by Monilinia fructicola. Plant Dis 81:399-403.

Burges HD, Jones KA. 1998. Trends in formulation of microorganisms and future research requirements. In: Burges, HD (Ed.), Formulation of Microbial Biopesticides, Beneficial Microorganisms, Nematodes and Seed Treatment. Kluwer Academic Publication, Dordrecht, pp. 311-332.

Droby S, Wisniewski M, El Ghaouth A, Wilson C. 2003. Influence of food additives on the control of postharvest rots apple and peach and efficacy of the yeast-based biocontrol product Aspire. Post Harvest Biol Technol 27: 127-35.

Fan Q, Tian SP. 2001. Postharvest biological control of grey mold and blue mold on apple by Cryptococcus albidus (Saito) Skinner. Postharvest Biol Technol 21:341-50.

Fravel DR. 2005. Commercialization and implementation of biocontrol. Ann Rev Phytopathol 43: 337-59.

Harti H. 2010. Control of fusarial wilt (Fusarium oxysporum f.sp. cubense (E F Smith)) of banana by using crabshell powder and chitosan. Master Thesis. Bogor Agricultural University, Indonesia. 
BIOTROPIA Vol. 20 No. 1, 2013

Karabulut OA, Smilanick JL, Mlikota Gabler F, Mansour M, Droby S. 2003. Nearharvest applications of Metschnikowia fructicola, ethanol, and sodium bicarbonate to control postharvest diseases of grape in central California. Plant Dis 87:1384-9.

Kinay P, Yildiz M. 2008. The shelf life and effectiveness of granular formulations of Metschnikowia pulcherrima and Picbia guilliermondii yeast isolates that control postharvest decay of citrus fruit. Biol Control 45: 433-40.

Multazam. 2002. Prospect for Utilization of shell of crab (Portunus sp.) as supplement of fish feed. Department of Fishery Product Technology. Bogor Agricultural University. Bogor (in Bahasa Indonesia).

Saligkarias ID, Gravanis FT, Epton HAS. 2002. Biological control of Botrytis cinerea on tomato plants by the use of epiphytic yeasts Candida guilliermondii strains 101 and US 7 and Candida oleopbila strain I-182: II. A study on mode of action. Biol Control 25: 345-6.

Santoso T, Prijono D, Wiyono S, Buchori D. 2005. Development, uses and application of biopesticides in Indonesia: current research and future challenge. Paper presented on International Conference on Biopesticides. Chiang-Mai Thailand, 13-18 February 2005.

Spadaro D. 2003. Biological Control of Postharvest Diseases of Pome Fruit Using Yeast Antagonists. PhD Thesis. Torino University. Torino.

Sugiprihatini D. 2009. The Use of Yeasts Antagonist and Chitosan to Control Stem End Rot Disease of Mango caused by Botryodiplodia theobromae Pat. in Storage (in Bahasa Indonesia). Master Thesis. Graduate School. Bogor Agricultural University.

Tian SP, Fan Q, Xu Y, Jiang AL. 2002. Effects of calcium on biocontrol activity of yeast antagonists against the postharvest fungal pathogen Rhizopus stolonifer. Plant Pathol 51:352-8.

Wiyono S, Schulz DF, Wolf GA. 2008. Improvement of the formulation and antagonistic activity of Pseudomonas fluorescens B5 through selective additives in the pelleting process. Biol Control 46:348-57.

Wiyono. S. 2008. Biological Control of Petal Blight of Dendrobium caused by Curvularia pallescens. Research Report (in Bahasa Indonesia) Departemen of Plant Protection Faculty of Agriculture IPB. Bogor.

Vivekananthan R, Ravia M, Saravanakumara D, Kumarb N, Prakasama V, Samiyappan R. 2004. Microbially induced defense related proteins against postharvest anthracnose infection in mango. Crop Prot 23: $1061-7$.

Yu TL, Yin WY, Wang Y, Zheng X. 2007. Effect of chitin on the antagonistic activity of Cryptococcus laurentii against Penicillium expansum in pear fruit. Int J Food Microbiol 122: 44-8. 